\title{
Positioning the Gendered Subaltern: Body, Speech and Resistance in Mahasweta Devi's Narratives
}

\author{
Joe Philip, ${ }^{1}$ Renu Bhadola Dangwal' ${ }^{2}$ \& Vinod Balakrishnan ${ }^{3}$ \\ ${ }^{1}$ Research Scholar, English, Department of Humanities and Social Sciences \\ National Institute of Technology, Uttarakhand, Srinagar, Garhwal, Uttarakhand-246174, \\ Email id:joephilip.phd14@nituk.ac.in.0RCID: oooo-0oo2-7593-046X \\ ${ }^{2}$ Assistant Professor, English, Department of Humanities and Social Sciences \\ National Institute of Technology, Uttarakhand, Srinagar, Garhwal \\ Uttarakhand-246174, Email id: rbdangwal@nituk.ac.in. ORCID: oooo-ooo2-7929-1570 \\ ${ }^{3}$ Professor, Department of Humanities, National Institute of Technology, Tiruchirappalli, \\ Tamil Nadu-620015, Email id: vinod@nitt.edu
}

\begin{abstract}
The postcolonial theory locates subaltern women as 'doubly effaced' and distanced from achieving agency to speak and participate in resistance. Due to her diversified colonized identity, much of the critical thought does not see any possibility for subaltern women participating in resistance. This line of argument implies a critical space in which the engagement with problematics inevitably leaves out subaltern women in the emergent resistance discourse. Moreover, such a position is suggestive of perceiving human activity and experience in closed terms and an intent to preserve subalternity. The present paper argues that, if perceived through a wider understanding of the concept of resistance, subaltern women may be seen to achieve agency as they communicate their plight vocally or silently and participate in resistance. Taking inferences from the literary narratives of Mahasweta Devi like Imaginary Maps, Breast Stories, the paper examines the strategies Devi employs to bring marginalized women into resistance and establishes that the 'body' emerges not only as a site of oppression but also as an important trope of power and resistance in her stories.
\end{abstract}

Keywords: gendered subaltern, doubly colonized, agency, hegemony and resistance.

The postcolonial theory has emerged as potential strategy to examine the power structures and their role in forming the socio-cultural framework in recent past. The politics of representation and domination and the dialectical relationship between the subaltern and the powerful elite constitute its core. The question of position of gendered subaltern and their representation and participation in speech and resistance has secured a central space in this discourse. Much of what has been said about in this regard, locates subaltern women "doubly effaced" (Spivak 1988, 83) and distanced from achieving agency to speak and participate in resistance due to the "lack of possibility of response and responsibility" (Spivak in Kock 1992, 46) towards subaltern female. It is so that in the critical as well as creative thought, gendered subaltern has erupted merely as a as

(C) AesthetixMS 2020. This Open Access article is published under a Creative Commons Attribution Non-Commercial 4.o International License (http://creativecommons.org/licenses/by-nc/4.o/), which permits non-commercial re-use, distribution, and reproduction in any medium, provided the original work is properly cited. For citation use the DOI. For commercial re-use, please contact editor@rupkatha.com. 
a site of domination. Partha Chatterjee also observes that “the 'Woman Question' ceases to become an issue for nationalist discourse by the end of the nineteenth century and argues that it is in fact 'resolved' by a necessary kind of silence" (Visweswaran 2014, 85). This line of argument implies a critical space in which the problematics inevitably leaves out subaltern women in the emergent resistance discourse, a charge which is labelled on Subaltern Studies Group.

The aim of the present study is to look at these critical spaces, through the narratives of Mahasweta Devi whose narrative world is densely populated with women folk of dispossessed adivasi community and landless labourers. Devi, in her enthnographic enquiry into the ontology of subaltern female existence, brings out the colonial forces and patriarchy, which "act as analogous to each other" and "exert control over female colonial subjects, who are, thus, doubly colonized" (Ashcroft 89). In large part of her narratives, as Mary Cappelli (2016, 2) says, "capitalist forces have penetrated female reproductive spaces disposing them to sexualized and commodified sites of exploitative fluctuating ideological values." But if considered within the prism of the ontological reality of speech (communication) and resistance, Devi' account of dispossessed women does not just talk about acquiescent females but at many places emerge as potential power center of resisting forces against the oppressive powers (hegemony). Spivak's concept of 'responsible resistance' focuses on this relationship between speech and resistance when she says that "when the subaltern 'speaks' in order to be heard and gets into the structure of responsible (responding and being responded to) resistance, he or she is or is on the way to becoming an organic intellectual" (2001, xxi). Many of Devi's women characters display strength and seek to participate in resistance and may be seen heading towards organic intellectuality. Spivak's view demystifies the blurriness and misconception of her rhetorical question 'Can the subaltern speak?' which supposedly denies speech to subalterns. The participation of gendered subaltern into speech and resistance, as Devi depicts in her narratives, throws light on the subaltern epistemology and resistance. The entry of gendered subaltern into the circle of hegemony and resistance by getting into speech elaborates the shifting of position. It suggests transformation from subalternity to achieving response from the other side.

The socio-cultural imbrications in speech and resistance are required to be accessed to understand gender resistance. The process of speech or communication is not only about speaking, it is about getting a response also. It is a two-way process which requires participation from both sides. The response may be of any kind ranging in variety and degree and cannot be put in categories and classification. Spivak's usage of terms 'responsible resistance' and 'ethical singularity' explain this correspondence between speaker and listener/onlooker. Once someone gets into speech and achieves this responsibility, one gets into the space of existence and mutual relationship.

Similarly resistance which ordinarily means the refusal to accept or comply with something has wider connotation in postcolonial/subaltern studies as it refers to oppose or to fight against any threat to existence. Contextualizing it in the wider hegemonic structure, Uday Chandra perceives the term "as negotiation rather than negation of social power" $(2015,563)$ to achieve agency. Resistance as negotiation allows the study of "wide range of contentious politics from foot-dragging through protests to social revolutions under a single analytic umbrella" (Chandra, 563). From this conception of resistance, it may be inferred that resistance also is not a static state rather a dialectic process, a continuum, in which subjugating forces remain actively engaged with opposing forces towards achieving rights and socio-political positioning in varying degrees. Throughout Devi's narratives like Imaginary Maps, Breast Stories, Outcast, The Glory of Sri Sri Ganesh, Mother of 1084, Bayen; feminine resistance may be seen engaged in speech and 
participating in resistance. Mary, Douloti, Dopdi, Gangor, Sujata, Lachhima, Rukmani respond, and resist in their own ways to their situations. These situations and responses cannot be brought to any strict definition out of the incommensurability of subjective experiences. They are varying forms of resistance: feeble at times, leading to the most fierce and direct, individual reactions to the collective protests, from most common to the unconventional ones.

In no other work body emerges as important a trope as in Mahasweta Devi's work. It is primarily a 'body'- both as corporeal frame as well as an embodiment of self that predominates in Devi's representation of subaltern experiences. Body is the basic and minimalist form of existential reality. Therefore the basic priority of existenial reality is to maintain physical survival and sustenance. When this physical survival is made impossible in terms of starvation, deprivation, disease, physical pain, torture, trauma, rape, killings; it is the body that gets into the centre. In human rights discourse, body emerges as "elemental priority" (Ignatieff 2001, 173). In the same context, Pramod Nayar considers that it is the most basic assumption of human existence to "possess (in the full and the true sense) a body $(2012,29)$ and any defiance to the basic rights is foregrounded in the "language of the body" $(2012,29)$. In the case of gendered subaltern, Devi sees body as the most important trope in communication. She depicts female body as site of struggle and a site of dominance- a "metonymic text of subaltern conspiracy and treachery (Battacharya 1996) but at the same time she also depicts it as an important dialogic connect between the master and the slave, between the oppressor and the oppressed, between the speaker and the listener. It is the 'body' that Devi brings into the forefront in form of physical pain and torture borne by adivasi women. But it is this body again which she brings "into speech" (Spivak in Kock 1996, 46) in the most intense and implicit manifestations. A brief examination of Devi's narratives may well support the argument.

The first story in Imaginary Maps, "The Hunt" celebrates the transformation of local festival into an act of emancipation when Mary Oraon, the adivasis young girl, kills her tormentor and possible rapist just before the act of rape. Mary, who is daughter of Oraon mother and English father, is a young woman of untamed spirit. She loves Jalim, a muslim boy, and plans to marry him. But she is always tormented by Tehsildar Singh's lustful offers. At the night of Jani Parab when all the local women eat and drink and enjoy themselves, Mary brings Tehsildar to utter languor with her intoxicated charms and puts an end to all the fears of getting raped. For Spivak, the story depicts "an individual activating ritual into contemporary resistance" and "Mary's negotiations with resources of the other side" (2001, 206-207).

In comparison to Mary, Douloti case is complex as she is the most reticent of Devi's female characters. It is here that Devi brings gendering as the biggest hurdle in the way of achieving speech and agency. Douloti, a fourteen year Nagesia girl, is sold for three hundred rupees as her father fails to repay three hundred rupee loan borrowed from the landloard Munabar Chandela. She turns a bonded labour, a kamiya-whore who ends up with "the body hollow with tuberculosis, the sores of venereal disease all over her frame, oozing evil-smelling pus, the whores come to hospital only to die" (Devi 2001, 92). In the brothel house, Dauloti requests Paramananda, "God! Your three hundred rupees have come through five times. Set me free then" (Devi 2001, 76)? But every time she gets the same answer: "your money has now increased by interest to two and a half thousand ... When it's repaid in principal and interest, you will be freed (Devi 2001, 76). As the money would never be repaid, Douloti has nothing left to say further. She reaches at such a point where her perpetrator fails to reach her. She tries to make her point but fails to be heard. Spivak consideres that through Douloti Mahasweta Devi "dramatizes the difficult truth" and says that this "internalized gendering perceived as ethical choice is the hardest roadblock for women the 
world over" (2001 xxiv). Though Spivak sees Douloti as the dark reality of those constraints which prevent women from attaining intellectuality for Douloti never participates in resistance as Mary does but Douloti registers her resistance in two significant ways. First, as Sanatan Bhowal (2016, 136) notices, Dauloti's “complete sexual passivity is her only form of resistance." For him, Douloti's exploitrators only want her body and have control over it by force. They do not see that in such a situation "there is no question of subaltern body participating in pleasure" and "in doing so they are themselves denied pleasure" (2016, 136). Douloti's body does not act the way her tormentors want, it does not respond. When they do not listen to her, her body also becomes sterile. She denies her rapists what they want from her. Second that in her most fragile condition, Douloti makes her choice and tries to speak in her own capacity. She leaves whorehouse and dies in the midway to her village. Devi crafts these moments very thoughtfully to explore adivasi women's last struggle to reach back her village. With each shaky step on the road to her village, Douloti exposes her tortures to the world and dies in front of school preparing to celebrate Independence Day. Devi writes, "here lies bonded labour spread eagled, kamiya-whore Douloti Nagesia's tormented corpse, putrefied with venereal disease, having vomited up all the blood in its desiccated lungs" (Devi 2001, 94). The signs of pain and suffering cry out loud. In his context, Nayar writes:

The body is the referent for all the cultural, social and economic trauma in a particular social order. It is the immediacy of the body, and its visible damages and behavior, that serve as the referent to something as 'abstract' as 'cruelty' or oppression. . . . When the victim 'shows' us her/his damaged, trembling, starving body s/he shows the form and nature of subjectivity's interaction with the world: 'this is how I have been treated by the world." $(2012,42)$

However passive and week such an interaction may appear but it works as an active agent. As a third world academician and writer, Devi well knows what message she received by "a skeletal girl in the local hospital who could only pronounce the name of her village and nothing else" ( Devi 2001, xiii). In Douloti's decision to leave whorehouse is reflected adivasi women's move on the way towards emancipation. It is in her last act that Douloti represents not just herself but thousand other kamiya-women and speaks against the horrors of bonded slavery. Her symbolic death on the map of India shows that it is not a lonely incident rather in all over India, similar incidents take place. The shameful stain of the blood she vomited and shed on the map of India is a sign of disgrace that is found all over. In her seemingly eternal silence and vulnerability is implicit the most vehement fire against bonded slavery and domestic body labour.

In the entire corpus of Mahasweta Devi's fiction, "Draupadi" is the most representative of gender resistance and speech. Dopdi Mejhen is a powerful woman protagonist, a representative revolutionary of her adivasis community. She is the most wanted in the Operation Bakuli and participates in the guerrilla warfare with indigenous weapons. Along with her husband Dulna Majhi, she is the prime instigator in "[m]urdering Surja Sahu and his son, occupying upper-caste wells and tubewells during the draught, not surrendering those three young men to the police" (Devi 2010, 20). After her husband's killing in one of the confrontations, she is haunted by Senanayak's army and is gang-raped. But she stands and confronts with courage those who shamed and terrified her. Standing before them as naked and bleeding, she makes the rapists shameful and helpless because the force they used to undress her was not enough to dress her again. She uses her body as a powerful weapon towards which the offenders hesitate to look at in the daylight. Here Draupadi (Dopdi), both in her free and captured state, emerges as determined and courageous and that is why without any fear she challenges Senanayak, the army officer 
5 | Positioning the Gendered Subaltern: Body, Speech and Resistance in Mahasweta Devi's Narratives

saying, "What's the use of clothes? You can strip me, but how can you cloth me again? Are you a man" (Devi 2010, 37)? She spits on his shirt and says, "There isn't a man here that I should be ashamed. I will not let you put my cloth on me" (Devi 2010, 37). With her unconquerable willpower, she gives a challenge to Senanayak to counter her, "Come on, kounter me-come on, kounter me-" (Devi 2010, 37). It is her body that becomes an object of power and not of shame. She also pushes Senanayak with her breasts that were wounded by the soldiers during the gang rape. "For the first time Senannayak is afraid to stand before an unarmed target, terribly afraid" (Devi 2001, 37). Draupadi who suffers at night in silence turns to be invincible and unconquerable at day. In the first part of this story, Devi enables the protagonist to be resistant with weapons and in the next she grows stronger with her will power to confront all her opponents who shamed and frightened her. The gang-rape of Dopdi is brought in comparison and contrast to the ancient Draupadi. The unclothing of these two women may be understood as "political punishment by the representatives of the law" (Spivak 2010, 12) for their participation in man-dominating state politics. For Spivak, Dopdi's choice to remain naked in front of her molesters defeats the male strategy to reduce them vulnerable and week. Spivak writes, "It is when she crosses the sexual differtial into the field of what could only happen to a woman that she emerges as the most powerful 'subject"' (2010, 13).

In her Mother of 1084, Devi exhibits such a middle class woman who gains speech after her son Brati's death by developing a perception into his mission against the evils of exploitative society. Before Brati's death, "Nobody cared to understand why Sujata wanted to work, why she had made all the enquiries herself and found a job for herself. . .She was subservient, silent, faithful and without an existence of her own" (Devi 2011, 9). But after losing her son, she does not bother for the conventional boundations enforced on middle class women by the family and the society. Samik Bandyopadhyay rightly observes that "as far as Mahasweta Devi is concerned, that would be the one aspect that could rationalize the movement and Brati's death to a fairly aff luent, sensitive and enlightened mother, who had read in her son's special concern for her daily humiliation as a woman and her quiet, determined struggle for self-assertion and independence, which ironically gathers force and momentum from Brati's death" (in Devi 2010, xv). She becomes determined to evade the patriarchal hegemony that Dibyanath exercises over her. Even the indifference she displays at home after Brati's death shows the beginning of her resistance to the entire family. She starts questioning Dibyanath which till Brati's death she had never did:

Have you asked them to remove Brati's portrait to the second floor?

Is the room on the second floor locked?

Yes

Who has the kyes.

I have them.

Give me the keys. Sujata had taken the keys and gone upstairs (Devi 2011, 13).

Without taking into consideration her husband's demand to give up her job, Sujata sticks to her job. Devi writes: "Refusing to leave her job was Sujata's second act of rebellion. Her first act of rebellion was when Brati was two. She had refused to be a mother for a fifth time" (Devi 2oll, 47).Gayatri Devi rightly observes that both Sujata and Nandini in this work evolve as organic intellectuals as they try to understand the complexities and dilemmas that characterize subaltern decolonization. Devi depicts these socio-political complexities contrasting with Sujata's 
motherhood and her duties as a wife. For "motherhood being the most ethically persuasive mode of subordination in many patriarchal cultures" (Gayatri Devi, 2012, 15).

In The Glory of Sri Sri Ganesh, Lachhima and Rukmani represent subaltern agony and resistance. Lachhima, is mortgaged to Medini Singh, the landlord, as his son's nurse and care taker and a subject to Medini himself to satisfy his lust. Gulal, the grandmother of Lachhima, is asked by Medini to bring Lachhima, the teenage girl, to look after the motherless baby with a tempting offer."I'll give you three bighas of land. And ten rupees a month. When you leave, you'll get a cow" (Devi 2003, 3). No sooner she becomes a midwife to Medini's son, she had to succumb herself to Medini Narayan's sexual exploitation. It shows how a woman in the feudal landlord system lives a life of utter disappointment. There are also other woman characters, who undergo the similar bodily exploitation of equal gravity like Rukmani and Pallavi Shah. Despite knowing that the landlord will never allow, Lachhima gathers courage and ask her master to relieve her, "If you're getting rid of me anyway, let me go now, Malik. Let me have someone to lean on. Or else where will I go? When I' am forty? I've served you all these years, shall I serve Chotta Mailk for eight more years? You could keep a maid, no?"(Devi 2003, 24). Instead of feeling pity for her, out of his anger he kicked her and shouted at her "take the lower castes to bed, and they forget their place"(25). Unlike many girls who mostly succumb to such oppressive forces, the protagonist in this novel, scornfully talks to her grandmother for having mortgaged her. It would show the doubly colonized condition of a gendered subaltern. "I' am mortgaged. When I'm sucked dry, useless as an old cow, then he'll let me go"(Devi 2003, 32). The victimization of subaltern women is by the feudal landlords is clearly shown in this fiction. Devi Writes:

The lower castes had different roles to play at different times; sometimes these men and women were bonded labourers, sometimes debtors, sometimes they were landless farmers evicted from their land, sometimes kept women-these role were decided by the higher castes. Who usually spoke and the lower castes listened. This time to the women remained silent (2003, 28).

But Lachhima retaliates and speaks to the face of the landowner when she is offered money at the time of leaving. She retorts in an unforgiving tone: "Money! Hansli! You've ruined me, how can you undo that? How much money, how much gold, will it take? No, I shan't take anything. I bore as much as I could. May you live long. Malik! for all the years you indulged yourself, may you sicken as long!"(68). Lachhima's openness creates much ruckus among the lower castes and it mobilizes her people against the rich landlords. During the Holi procession the bhangis sing songs about the whole episode. They caricature Medini Singh and sing about the nasty way through which he crushed the life of Lachima and Mohor Karan. Even amidst the penury and destitution they demonstrate an adamant will: "The bhangis drank, turned into mud and colour-smeared demons, made themselves up like freaks, took out processions, composed songs. They composed songs about new laws, about murders and fights, about the oppression of the police and the scandals of the Maliks" (57). By composing songs about the rotten and pretentious life, they seek to undermine the culture of the elite classes. They fabricate mocking songs on the stinking private life of the masters. These songs can be viewed as a protestation at the cultural level by the They would make up a song on any stirring event, paint their faces and sing the song in the bazaar, to collect money"(42).

And at the end, when Ganesh, son of Medini Singh, reaches to Lachhima, who was once his caretaker, to save his life, she says, "Only I could have saved you then. Today, I shall save you again. But not, Ganesh Singh, in the way you want me to. Today, I shall do it my way" (164). Telling this, she brandished her sickle at him and loudly called out the people: "Wherever you are, 
come quick! Ganesh Singh had come to set fire to the forest, he's hiding in my hut. Wherever you are, hurry! Ganesh Singh is hiding here. Come quick!"(163) Lachhima is no more lonely rather the whole community joins hand to punish their common persecutor. "A sea of armed people, voices raised, surged around the house in mighty waves. Lachhima moved aside, leaving the door free, and became one with the crowd"(165). Thus, Lachhima, Rukmani and Horoa who the agency gained by the women exploited, through the medium of their community is very much eloquent therefore it can be said very clearly that the voice of the subaltern can be made listened.

In "Behind the Bodice", Gongor's resistance is portrayed more directly than Dopadi. Her negotiation with Upin for money dismantles his secret plan of making money by selling her photographs in the market. Earlier she asks for fifty-sixty rupees for her picture but gradually she starts asking for more money. Upin says to Ujan,

"Listen friend, I will sell these pictures . . . why shouldn't she take money? They are not dumb beasts Ujan, they understand that even when the gentlemen distribute some relief, they have some hidden agenda" (Devi 2010, 142).

She reprimands Upin for exploiting her like others and holds him guilty whatever has befalls her. Gongor shuns Upin's pride and makes him rethink, "Why did he first think that they [her breast] were the object of photography? Why did it seem that that chest was endangered?" Upin has no answer to Gongor's present state. Similarly Devi's "Bayen" describes Chandidasi's transformation from a submissive wife to a rebellious one to save herself from social victimization due to her job of burying dead children. After attaining motherhood, she wants to leave this job and declares to her husband to discontinue with it. Richa Gupta observes,

"her fury also gradually transforms into rebellion. She denies to undertake the task of burying the dead bodies. On the burden of the public, she becomes wild and does not hesitate to take action against violence and injustice" (68).

Even though in the case of many women, Mahasweta Devi confronts the problematics and complexities that perpetuate women's subalternity, the most important being the traditional gendering, yet she materializes both the active and passive resistance of women in significant ways. Believing that human experiences may not be encapsulated in theoretical pronouncements, Devi portrays gendered subaltern in all their realities. Her account of these adivasi women enlarges our perspective into the participation of gendered subaltern in speech, representation and resistance. It further extends the connotation of Spivak's question 'Can the Subaltern Speak?" by drawing these subaltern voices into the structure of responsible (responding and being responded to) resistance" and taking them "on the way to becoming organic intellectual" (Spivak 2001, xxi). The body takes the central place in her writings, gets into the speech and turns the discourse towards the other side. Thus, it is seen that her field based-ethnographic study into the history and socio-political standing of oppressed gender facilitates towards theorizing on the most troubling issues of contemporary relevance, particularly which relates to gendered subaltern and bridges the distance between theory and practice. She develops the possibility for an author to obliterate the imaginary gaps between various disciplines of enquiry in social sciences and humanities. 


\section{References}

Ashcroft, Bill, et al. eds. (2013). Post Colonial Studies: The Key Concepts. Third Edition. London and New York: Routledge.

Bhattacharya, Nandini (1996), "Behind the Veil: The Many Masks of Subaltern Sexuality”, Women's Studies International Forum. Vol.19, Issue 3, 277-292.. https://doi.org/10.1016/0277-5395(96)ooo15-5

Bhowal, Sanatan (2016), The Subaltern Speaks: Truth and Ethics in Mahasweta Devi's Fiction on Tribals. Hyderabad: Orient Blackswan.

Cappelli Mary (2016), "Tortured Bodies, rape and disposability in Mahasweta Devi's "Giribala", "Dhowli" and "Douloti the Bountiful". Cogent Social Sciences, Vol.2. Issue 1, https://doi.org/10.108o/23311886.2016.1232343.

Chandra Uday (2015), "Rethinking Subaltern Resistance", Journal of Contemporary Asia. Vol. 45, Issue 4, pp. 563-573, Taylor and Francis Online, Retrieved from https://www.tandfonline.com/doi/pdf/10.108o/o0472336.2015.1048415

Devi, Gayatri (2012), "Radical Failure: Mother of 1084 as a Subaltern Critique," Subaltern Vision: A Study in Postcolonial Indian English Text. Eds. Aparajita De et. al., United Kingdom: Cambridge Scholars Publishing. https://www.cambridgescholars.com/download/sample/6o555

Devi, Mahasweta (2011). Five Plays. Trans. Samik Bandyopadhyay. Calcutta: Seagull Books.

Devi, Mahasweta (2010). Breast Stories. Trans. Gayatri Chakravorty Spivak. Calcutta: Seagull Books.

Devi, Mahasweta (2001). Imaginary Maps. Trans. Gayatri Chakravorty Spivak. Calcutta: Thema.

Devi, Mahasweta (2011). Mother of 1084. Trans. Samik Bandyopadhyay. Calcutta: Seagull Books.

Devi, Mahasweta (2003). The Glory of Sri Sri Ganesh. Trans. Ipsita Chanda. Calcutta: Seagull Books.

Gupta, Richa (2017). Subaltern Studies of Mahasweta Devi. Jaipur: Aadi Publications.

Ignatieff, Michael (2001), Response to Commentators, Human Rights as Politics and Idolatry, Amy Gutmann, ed., Princeton: Princeton University Press, pp-161-173.

Kock Leon De (1992), "Interview with Gayatri Chakravorty Spivak: New Nation's Writers Conference in South Africa”, ARIEL: A Review of International English Literature. Vol. 23, pp. 29-47. Retrieved from http://jan.ucc.nau.edu/ sj6/Spivak\%2oInterview\%2oDeKock.pdf

Nayar Pramod K (2012), Writing Wrongs: The Cultural Construction of Human Rights in India. London: Routledge, ISBN: 978113850039-6.

N, Firoz (2006). “The Glory of Sri Sri Ganesh: Recuperating the Silenced” Writing for/with Subaltern: A Study of Contemporary Indian Fiction with Focus on Mahasweta Devi's Works. Thesis. Department of English, University of Calicut.

http://shodhganga.inflibnet.ac.in/bitstream/10603/38570/9/o9_chapter\%204.pdf

Spivak, Gayatri Chakravorty (1988), "Can the Subaltern Speak.” Retrieved from http://abahlali.org/files/Can_the_subaltern_speak.pdf

Spivak, Gayatri Chakravorty (2001), Preface. Imaginary Maps. Mahasweta Devi, Calcutta: Thema

Spivak, Gayatri Chakravorty (2010), Foreword. Breast Stories. Mahasweta Devi. Calcutta: Seagull Books.

Visweswaran, Kamala (2014). "Small Speeches, Subaltern Gender: Nationalist Ideology and its Historiography." Subaltern Studies: Writing on South Asian History and Society. Ed. Shahid Amin and Dipesh Chakrabarty. Vol.9. New Delhi: OUP. PP. 83-125. 
9 | Positioning the Gendered Subaltern: Body, Speech and Resistance in Mahasweta Devi's Narratives

Joe Philip is a Research Scholar of English at the Department of Humanities \& Social Sciences, National Institute of Technology, Uttarakhand. He has published two of his papers in international journals. He has presented five papers in national and international conferences held in India. He has done his masters in English from Hemwati Nandan Bahuguna, Central University, Srinagar, Uttarakhand.

Renu Bhadola Dangwal is Assistant Professor in the department of Humanities and Social Sciences, National Institute of Technology, Uttarakhand. She has published in several national and international journals and books. Her research pursuits explore central issues in postcolonial and eco-cultural studies including her reading of eco-cultural threat in Mahasweta Devi's narratives. She has also worked on indigenous experiences in the light of multiculturalism and human rights and has presented her studies in prestigious conferences and seminars.

Vinod Balakrishnan is Professor in the Department of Humanities and Social Sciences, National Institute of Technology, Tiruchirappalli where he teaches Creative Writing and Communication Skills. He is a practising poet, motivational speaker, reviewer of books and a yoga enthusiast. He reads on Life Writing, Somaesthetics, Film Studies and Representations of India. He has published in a/b autobiography studies, Partial Answers, HUMOUR, Journal of Dharma. 